\title{
HUBUNGAN HIPERGLIKEMIA DENGAN KADAR GLYCERALDEHYDE-3-PHOSPHATE DEHYDROGENASE (GAPDH) PADA PENDERITA DIABETES MELLITUS TIPE 2
}

\author{
Yessi Alza \\ Email: yessi.alza77@gmail.com
}

\begin{abstract}
Diabetes mellitus (DM) is a group of metabolic disease with characteristic hyperglycemia. Glycosylated hemoglobin $(\mathrm{HbA} 1 \mathrm{C})>7 \%$ indicated uncontrolled DM. Hyperglycemia causes excessive production of free radicals that trigger oxidative stress. Oxidative stress is caused primarily by superoxide anion mitochondrial DNA would undermine the core so that it will activate PARP. PARP is activated would inhibit the activity of GAPDH in the glycolytic pathway. Inhibited glycolysis pathway will lead to reactions that formed splinter polyol pathway, increased PKC and increased hexosamine pathway. The research design was cross sectional comparative study, conducted in Internal Medicine Department of Dr. M.Djamil Hospital in Padang, Biomedical Laboratory of Medical College, Chemical Laboratory of College of Mathematics and Physical Sciences Andalas University. The total number of samples are 70, divided into two group, consist of 35 people cases and 35 people controlled. ELISA method was used for examination of GAPDH activity.The research results are activity GAPDH in patients with T2DM in lower that the non DM, but not statistically significant. Regression correlation analysis for relationship between fasting blood sugar with the activity of GAPDH denoted weak correlation, $r=0,179(\mathrm{p}=0,139)$, and the relationship of blood glucose levels 2 hours post prandial with GAPDH levels in patients with T2DM obtained a weak correlation with $\mathrm{r}$ values = $0.039(\mathrm{p}=0.749)$. The research conclusion are there is no significant difference between GAPDH activity in patients with T2DM and non DM, there is a weak relationship between hyperglycemia with GAPDH activity.
\end{abstract}

Key words: Diabetes Mellitus Type 2, Hyperglycemia, Glyceraldehyde-3- Phosphate Dehydrogenase

\section{PENDAHULUAN}

Diabetes melitus (DM) merupakan suatu penyakit yang menjadi ancaman utama bagi kesehatan umat manusia pada abad 21. Berdasarkan perkiraan yang dibuat oleh World Health Organization (WHO) bahwa pada tahun 2000 jumlah pengidap diabetes melitus di atas umur 20 tahun berjumlah 150 juta orang dan dalam kurun waktu 25 tahun kemudian, pada tahun 2025, jumlah ini akan membengkak menjadi 300 juta orang. Data terakhir dari WHO menunjukkan bahwa terdapat kecendrungan peningkatan prevalensi DM yang lebih tinggi di negara- negara Asia Tenggara termasuk di Indonesia. Secara klinis DM dibedakan menjadi DM tipe 1 (DMT1) dan DM tipe 2 (DMT2). Kasus yang terbanyak adalah DMT2, yang merupakan masalah besar dibidang kesehatan. Di Indonesia, jumlah penderita DMT2 pada tahun 2000 adalah 8,4 juta orang dan diperkirakan jumlah ini akan meningkat pesat menjadi 21,3 juta orang pada tahun 2030 (Wild and Sicree, 2004)

Besarnya dampak yang ditimbulkan oleh DMT2 selain disebabkan oleh semakin tingginya prevalensi DMT2 juga diakibatkan oleh berbagai komplikasi yang 
ditimbulkannya. Komplikasi DMT2 berupa penyakit kardiovaskuler, penyakit pembuluh darah perifer, stroke, kebutaan dan gagal ginjal yang sangat mengurangi kualitas hidup sehingga akan melambungkan biaya kesehatan pada masyarakat terkait, DMT2 dapat mengenai segala lapisan masyarakat, segala strata ekonomi, semua golongan umur baik pria maupun wanita ( Alberti et al., 2007), bahkan dilaporkan DMT2 merupakan penyebab kematian nomor 6 di Amerika Serikat pada tahun 2002 dan peringkat ke 5 di seluruh dunia. ( Fauci et al., 2008)

Riset Kesehatan Dasar (Riskesdas), 2007 Indonesia diketahui bahwa penyebab kematian akibat DM pada kelompok usia 4554 tahun di daerah perkotaan menduduki ranking ke-2 yaitu $14,7 \%$. Dan daerah pedesaan, DM menduduki ranking ke-6 yaitu $5,8 \%$. Sedangkan dari data Departemen Kesehatan, jumlah pasien DM yang dirawat inap maupun rawat jalan di rumah sakit menempati urutan I dari seluruh penyakit endokrin.. Hal ini tidak hanya karena prevalensinya yang semakin meningkat, tapi juga karena DM menyebabkan kerusakan hampir pada seluruh jaringan tubuh. Dari seluruh penderita DM tingkat kekerapan DMT1 sekitar 10-20\% dan DMT2 adalah 8090\% ( Suyono, 2006)

Diabetes mellitus adalah keadaan dimana terjadi peningkatan kadar glukosa plasma dari nilai normalnya yaitu $\geq 200 \mathrm{mg} / \mathrm{dl}$ pada pemeriksaan glukosa darah sewaktu atau $\geq$ $126 \mathrm{mg} / \mathrm{dl}$ pada saat puasa. Dalam membicarakan DM pasti tidak lepas dengan istilah hiperglikemia. Hiperglikemia disebabkan kelainan sekresi insulin atau gangguan kerja dari insulin (Rand and Murray, 2001; Johansen et al., 2005).

Kadar glukosa tinggi didalam sel akibat hiperglikemia terlibat dalam pembentukan radikal bebas (ROS). Tingginya kadar glukosa didalam sel akan menyebabkan kerusakan pada DNA mitokondria. Kerusakan ini akan mengaktivasi poly (ADPribose) polymerase (PARP). Peningkatan aktivitas PARP pada DMT2 telah dilaporkan oleh Yerizel E pada tahun 2011. Aktivasi PARP akan menghambat aktivitas glyceraldehyde-3-phosphate dehidrogenase (GAPDH).

\section{Glyceraldehyde-3-phosphate}

dehidrogenase (GAPDH) adalah enzim yang mengkatalisis gliseraldehyde-3-fosfat menjadi 1,3 bisfosfogliserat pada jalur glikolisis. Dengan terhambatnya aktivitas GAPDH, maka jalur glikolisis akan terganggu. Terganggunya jalur glikolisis maka pembentukan energi akan terhambat dan juga menimbulkan beberapa mekanisme reaksi sempalan (single unifying mechanism), yaitu melalui peningkatan polyol pathway flux, peningkatan ekspresi reseptor untuk advanced glycation end product (AGEs), peningkatan aktivitas dari jalur hexosamine, dan peningkatan aktivasi isoform protein kinase $\mathrm{C}$ (PKC). (Du Xueliang, et al 2003)

Jalur polyol diperankan oleh enzim aldose reduktase. Enzim ini mampu mengubah aldehid yang toksik menjadi alkohol inaktif. Pada konsentrasi glukosa yang sangat tinggi. Glukosa ini akan diubah menjadi sorbitol dan akhirnya menjadi fruktosa. Mekanisme ini membutuhkan donor nicotinamide adenine dinucleotide phosphate hidrogenase (NADPH). NADPH diketahui berperan sebagai antioksidan melalui system glutation. Dengan demikian konsentrasi glukosa tinggi memperparah stres oksidatif yang terjadi pada sel ( Du Xueling et al, 2003)

Pembentukan AGEs dimulai dengan pembentukan produk glikosilasi awal. Glikosilasi non enzimatik diawali dengan menempelnya glukosa pada gugus asam amino, berlanjut dengan serangkaian reaksi 
dengan hasil terbentuknya Amadory products, dan selanjutnya berakhir sebagai AGEs yang bersifat ireversibel.( Du Xueliang, et al. 2003)

Hiperglikemia dapat juga meningkatkan diacylglycerol (DAG) dan kenaikan DAG akan meningkatkan aktivitas PKC. Aktivasi PKC isoform $\beta$ menyebabkan perubahan fungsi sel vaskuler melalui aktivasi fosfolipase A2. Dapat disimpulkan bahwa semua mekanisme reaksi sempalan tersebut diatas bersifat aterogenik sehingga mempercepat timbulnya komplikasi DM .(Giacco F, Brownlee M, 2010)

Rumusan masalah penelitian ini adalah: Apakah ada hubungan hiperglikemia terhadap kadar GAPDH pada DMT2 ?. Tujuan penelitian ini adalah untuk mengetahui hubungan hiperglikemia terhadap kadar GAPDH pada DMT2 dengan Non DM.

\section{METODOLOGI PENELITIAN}

Penelitian ini merupakan penelitian observasional dengan pendekatan Cross sectional comperative dimana variabel dependen dan independen diperiksa dalam waktu bersamaan. Variabel independennya adalah kadar gula darah sewaktu dan kadar gula darah puasa. Variable dependen adalah kadar glyceraldehydes-3- phosphate dehidrogenase. Penelitian dilakukan di 1). Bagian Penyakit dalam RSUP Dr.M Djamil Padang, 2). Laboratorium Biomedik Fakultas Kedokteran Unand. Penelitian ini dilakukan pada bulan April sampai Juni 2012.

Sampel penelitian ini adalah bagian dari populasi yang mempunyai kriteria inklusi dan ekslusi. Sebagai kontrol adalah orang sehat yang tidak menderita DM yang berasal dari karyawan RSUP Dr. M. Djamil, karyawan Fakultas Kedokteran Unand dan masyarakat di sekitar kampus Fakultas Kedokteran Unand. Besar sampel pada penelitian ini adalah 35 orang kasus dan 35 orang sebagai kontrol

Objek penelitian adalah penderita DMT2 yang tidak terkontrol yang mempunyai kadar HbA1c $>7 \%$. Pengambilan sampel dilakukan secara eksekutif random terhadap penderita DMT2 yang menjalani rawat jalan maupun dirawat inap di Bagian Penyakit Dalam RSUP Dr.M.Djamil Padang. Sebagai pembanding kontrol yang tidak menderita DM. Pada setiap sampel diambil darah vena sebanyak $10 \mathrm{ml}$. Pengukuran HbA1C, kadar glyceraldehydes-3-phosphate dehydrogenase (GAPDH) dilakukan terhadap serum.

Untuk membandingkan kadar GAPDH antara penderita DM dan Non DM menggunakan uji T. Sedangkan untuk menganalisis ada tidaknya hubungan hiperglikemia yang ditujukan oleh kadar gula darah puasa dan kadar gula darah 2 jam PP dengan GAPDH menggunakan korelasi regresi.

\section{HASIL DAN PEMBAHASAN}

Karakteristik Responden Penelitian

Tabel 1.

Distribusi Frekuensi Responden Berdasarkan Umur

\begin{tabular}{|c|c|c|c|}
\hline \multirow{2}{*}{ Karakteristik } & \multicolumn{2}{|c|}{ Rerata \pm SD } & \multirow{2}{*}{ p } \\
\cline { 2 - 3 } & DMT2 & Non & DM \\
& & & \\
\hline Umur (tahun) & $52,51 \pm$ & $49,63 \pm$ & 0,021 \\
& 4,44 & 5,74 & \\
\hline
\end{tabular}

Pada tabel diatas terlihat rerata umur pada kelompok penderita DMT2 adalah $52,51 \pm 4,44$ tahun dan umur rata-rata pada kelompok Non DM adalah 49,63 \pm 5,74 tahun. Setelah dilakukan uji statistik kedua kelompok umur pada penderita DMT2 dan Non DM didapatkan perbedaan yang bermakna dengan nilai $p<0,05$. Karakteristik responden berdasarkan umur 
antara DMT2 dengan non DM tidak sama hal ini dapat mempengaruhi hasil dari penelitian

Tabel 2.

Distribusi Frekuensi Responden Berdasarkan Jenis Kelamin

\begin{tabular}{|c|c|c|c|c|}
\hline \multirow[b]{2}{*}{$\begin{array}{c}\text { Jenis } \\
\text { kelamin }\end{array}$} & \multicolumn{2}{|c|}{ DMT 2} & \multicolumn{2}{|c|}{ Non DM } \\
\hline & $\begin{array}{c}\text { Freku } \\
\text { ensi }\end{array}$ & $\%$ & $\begin{array}{c}\text { Freku } \\
\text { ensi }\end{array}$ & $\%$ \\
\hline $\begin{array}{l}\text { Laki- } \\
\text { Laki }\end{array}$ & 19 & 54,3 & 19 & 54,3 \\
\hline $\begin{array}{c}\text { Perempu } \\
\text { an }\end{array}$ & 16 & 45,7 & 16 & 45,7 \\
\hline Total & 35 & 100 & 35 & 100 \\
\hline
\end{tabular}

Berdasarkan tabel diatas jenis kelamin penderita DMT2 yang diteliti dan kelompok kontrol terdiri dari 19 orang laki-laki $(54,3 \%)$ dan perempuan 16 orang $(45,7 \%)$. Jenis kelamin perempuan dan laki-laki pada penderita DMT2 dan Non DM sudah setara, dengan persentasi yang sama pada kedua kelompok

\section{Perbedaan Kadar GAPDH pada Penderita DMT2 dan Non DM}

Tabel 3.

Perbedaan Rerata Kadar GAPDH pada Penderita DMT2 dan Non DM

\begin{tabular}{|c|c|c|c|}
\hline \multirow{2}{*}{} & \multicolumn{2}{|c|}{ Rerata \pm SD } & \multirow{2}{*}{$\mathrm{p}$} \\
\cline { 2 - 3 } & DMT2 & Non DM & \\
\hline Kadar & & $0,78 \pm$ & \multirow{2}{*}{0,25} \\
GAPDH & $0,64 \pm 0,39$ & 0,59 & \\
(unit/mg) & & 0,5 \\
\hline
\end{tabular}

Dari tabel diatas dapat terlihat bahwa rerata kadar GAPDH pada penderita DMT2 lebih rendah dari kadar GAPDH non DM.

Dengan kadar rerata GAPDH pada penderita DMT2 adalah 0,64 \pm 0,39 dan kadar rerata GAPDH pada non DM 0,78 \pm 0,59 . Perbedaan ini tidak bermakna secara statistik dengan nilai $\mathrm{p}>0,05$.

Pada tabel diatas terlihat bahwa rerata kadar GAPDH pada penderita DMT2 adalah $0,64 \pm 0,39$ unit/mg, sedangkan non DM adalah $0,78 \pm 0,59$ unit/mg. Hasil penelitian ini menunjukkan bahwa tidak adanya perbedaan rerata kadar GAPDH pada kelompok DMT2 dibandingkan dengan kelompok non DM. Walaupun secara statistik tidak menunjukkan hasil yang bermakna tetapi apabila dilihat dari rerata kadar GAPDH pada penderita DMT2 lebih rendah dibandingkan non DM.

Mekanisme ini disebabkan oleh karena kenaikan kadar gula darah yang tidak terkendali pada penderita DMT2 sehingga menyebabkan hiperglikemia. Hiperglikemia dapat peningkatan produksi spesies reaktif (ROS) dan akan memicu terjadinya stress oksidatif. Hal ini akan menyebabkan rusaknya DNA inti ( DNA Damage ). Rusaknya DNA inti menyebabkan teraktivasinya PARP. Teraktivasinya PARP akan menghambat aktifitas GAPDH. Terhambatnya aktivitas GAPDH di dalam sel akan menyebabkan proses glikolisis terganggu sehingga menimbulkan reaksi sempalan .

Reaksi - reaksi yang timbul akibat terhambatnya aktivitas GAPDH di dalam sel akan menyebabkan terjadinya disfungsi endothel yang akan mempercepat terjadinya komplikasi pada diabetes. (Ceriello A, 2005)

Hubungan Kadar Gula Darah Puasa dengan kadar GAPDH Pada DMT2

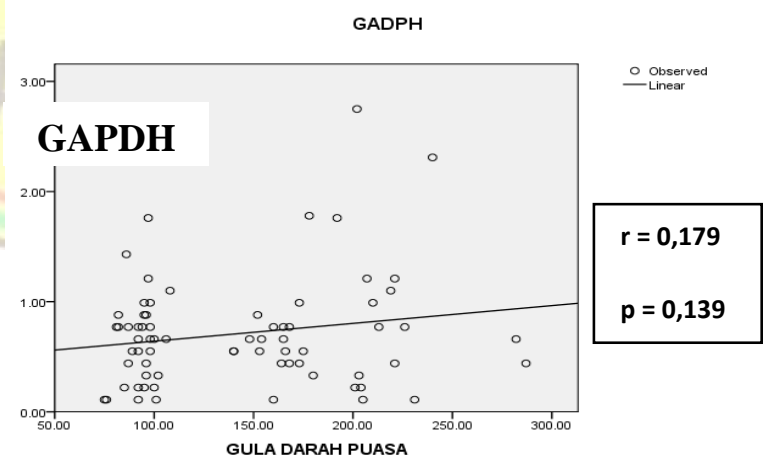

Gambar 1. Hubungan Kadar Gula Darah Puasa dengan kadar GAPDH pada Penderita DMT2

Dari gambar diatas terlihat bahwa adanya hubungan antara kadar gula darah 
puasa dengan kadar GAPDH pada penderita DMT2. Semakin tinggi kadar gula darah puasa semakin tinggi kadar GAPDH. Dari analisis korelasi kadar gula darah puasa dengan kadar GAPDH diperoleh korelasi sangat lemah yaitu 0,179 dan secara statistik tidak bermakna $\mathrm{p}>0,05$.

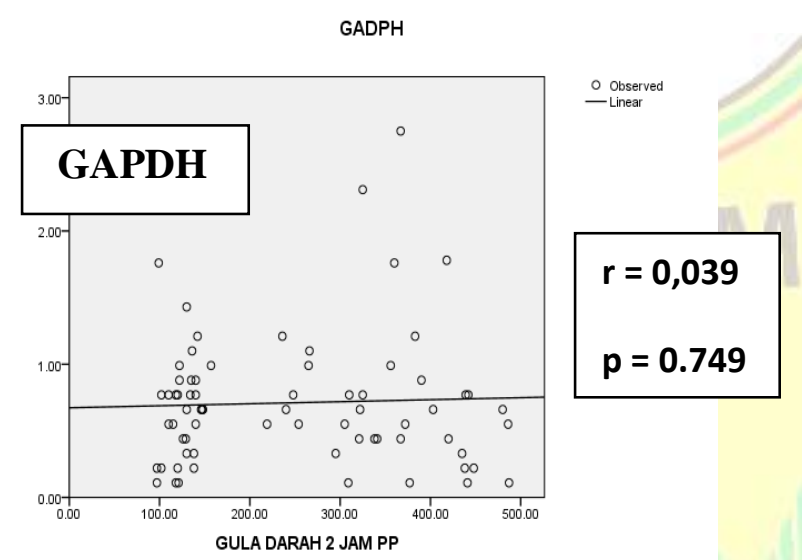

Gambar 2. Hubungan Kadar Gula Darah 2 jam Post Prandial dengan kadar GAPDH pada penderita DMT2

Dari gambar diatas terlihat bahwa adanya hubungan antara kadar gula darah 2 jam post prandial dengan kadar GAPDH pada penderita DMT2. Semakin tinggi kadar gula darah 2 jam post prandial semakin tinggi kadar GAPDH. Dari analisis korelasi kadar gula darah puasa dengan kadar GAPDH diperoleh korelasi sangat lemah yaitu 0,039 dan secara statistik tidak bermakna $\mathrm{p}>0,05$. Berdasarkan gambar 5.1 terlihat bahwa hubungan antara kadar gula darah puasa dengan kadar GAPDH pada penderita DMT2 menunjukkan korelasi yang lemah ( $\mathrm{r}=$ 0,179). Berdasarkan analisis korelasi peningkatan kadar gula darah puasa diikuti oleh peningkatan kadar GAPDH dalam darah. Namun secara statistik tidak terdapat hubungan yang bermakna dengan nilai $\mathrm{p}>$ 0,05 .

Pada gambar 5.2 terlihat bahwa hubungan antara kadar gula darah 2 jam post prandial dengan kadar GAPDH pada DMT2 menunjukkan korelasi sangat lemah dengan nilai $r=0,039$. Berdasarkan analisis korelasi regresi peningkatan kadar gula darah 2 jam post prandial diikuti kecendrungan peningkatan kadar GAPDH pada penderita DMT2. Namun secara statistik tidak bermakna dengan nilai $\mathrm{p}>0,05$.

Pada studi yang dilakukan oleh Nishikawa et al, 2000 didapati peningkatan produksi spesies oksigen reaktif (ROS) oleh rantai transport elektron mitokondria yang diinduksi oleh hiperglikemia akan menyebabkan rusaknya DNA mitokondria dan DNA inti ( DNA Damage) yang berakhir pada disfungsi mitokondria, selain merusak DNA mitokondria juga menyebabkan PARP teraktivasi. Aktivasi PARP mengakibatkan aktivitas GAPDH terhambat. Pada studi yang dilakukan oleh XL Du et al, 2000 kelebihan produksi hiperglikemia yang disebabkan oleh superoksida mitokondria, mengakibatkan penurunan $66 \%$ aktivitas GAPDH di dalam sel. Penelitian yang berbeda juga dilakukan oleh XL Du et al, 2003 pada kultur sel endothel yang diinduksi glukosa $30 \mathrm{~mm}$ (milimol) menurunkan aktivitas GAPDH sebesar $73 \%$ dari $0,157 \pm 17,6 \mathrm{unit} / \mathrm{mg}$ menjadi $0,042 \pm 10,5$ unit/mg. Terganggunya jalur glikolisis akibat inaktivasi GAPDH mengakibatkan terbentuknya 4 jalur utama yaitu peningkatan jalur polyol, peningkatan jalur hexosamine, peningkatan AGE dan peningkatan jalur PKC melalui diacylglycerol

Berdasarkan sifat enzim pada saat terjadinya kerusakan sel akan menyebabkan enzim intra seluler keluar dan masuk kedalam sirkulasi (darah) sehingga kadarnya menjadi meningkat di dalam darah. Berdasarkan penelitian yang dilakukan Brownlee, 2001 bahwa peningkatan produksi superoxide mitokondria yang diinduksi oleh hiperglikemia merupakan awal terjadinya komplikasi diabetes. 
4. KESIMPULAN

1. Tidak terdapat perbedaan yang bermakna rerata kadar GAPDH pada penderita DMT2 dengan non DM.

2. Terdapat korelasi yang lemah antara kadar gula darah puasa dengan kadar GAPDH

3. Terdapat korelasi yang lemah antara kadar gula darah 2 jam pp dengan kadar GAPDH

\section{DAFTAR PUSTAKA}

Abate C, Patel L, Raucher FJ III, 1990. Redox Regulation of fos and jun DNA-binding activity in vitro. Science. 249;1990:1157-61

American Diabetes Association, 2001. Management of Dyslipidemia in Adults with Diabetes. Diabetes Care 2004; 24 (suppl 1): S58-S61.

American Diabetes Association. 2004. ADA

Position Statement: Standard of Medical Care in Diabetes. Diabetes Care; 29 (suppl 1): S4-S42.

Alberti KGM, Zimmet P, Show J. 2007. International Diabetes Federation: a concensus on Type 2 diabetes prevention. Diabetec Medicine, 24,451-63.

Bender David, Mayes Peter. 2009. Glikolisis dan Oksidasi Piruvat. Dalam: Muray RK, Granner DK, Mayes PA, Rodwell VW. Biokimia Harper. Edisi 27. Alih Bahasa: Brahm U. Jakarta: EGC. 2009: 160 - 158 .

Brownlee M. 2001. Biochemistry and molecular cell biology of diabetic complications. Nature. 414: 813-20.

Brownlee M. 2005. The Pathobiology of Diabetic Complications A Unifying Mechanism. Diabetes: vol 54:

Ceriello Antonio. 2006. Perspectives in Diabetes Postprandial Hyperglycemia and Diabetes Complications. Diabetes; vol 54

Djokomoeljanto R, 2007. Neuropati Diabetik: Naskah lengkap diabetes mellitus ditinjau dari berbagai aspek penyakit dalam. Editor: Darmono. Suhartono T, Pemayun TGD, Padmodarmono FS. Semarang: Badan Penerbit Universitas Diponegoro. 4-9.

Droge W. 2002. Free Radicals in The Physiological Control of Cell Function. Physiol Rev. 82; 47 -95

Du XL, Edelstein D, Rossetti L, Fantus IG, Goldberg H, Ziyadeh F, et al. 2000. Hyperglycaemia induced mitochondrial superoxide overproduction activates the hexosamine pathway and induces plasminogen activator inhibitor-1 expression by increasing Sp1 glycosylation. Proceedings of the National Academy of Sciences of the USA; 97: 12222-6

Du XL, Matsumura T, Edelstein D, Rossetti L, Zsengeller Z, Scabo C, et al. 2003. Inhibition of GAPDH activity by poly(ADP-ribose) polymerase activates three major pathways of hyperglycemic damage in endothelial cells. The Journal of Clinical Investigation; No; 7; Vol 112

Fauci A, Kasper D, Longo D. 2008. Horrison's Principle of Internal Medicine. USA: MGraw - Hill Companies.

Gallagher E, Raith D, Bloomgarden Z. 2009. Review of Hemoglobin A1C in The Management of Diabetes. Journal of diabetes: 1:9-17

Giacco F, Brownlee M. 2010. Oxidative stress and Diabetic Complications: Circulation Research. 107: 1058-1070

Inoue M, 2001. Protective Mechanism Againt Reactive Oxygen Species. In: 
Arisas IM The liver biology and pathobiology Lippincott Williams and Wilkins 4th-ed. Philadelphia. 2001: 281-90

Islam M, S, and Lout D, T, 2007. Diabetes, Metallothionein, and Zinc Interaction: a review. Biofactors: 29; 2003-212

Johansen, Hartis AK, Rishly D. 2004. Oxidative Stress and The use of Antioxidant in Diabetes: Lingking basic science to clinical practice. Cardiovasc Diabetol. 4 (s); 1-11.

Jusman SWA, 1999. Konsep-Konsep Dasar Biokimia Dalam Diabetes Mellitus. Dalam understanding icular diabeticbasic science, clinical aspect and didactic course. FKUI: 1-5.

Karam JH, 1996. Pancreatic Hormones and Diabetes Mellitus. In Greenspan, F.S.,

Basic and clinical Endocrinology; 3rd Ed, 593 - 649. Prentice-Hall International Inc., London.

Kowluru RA, Tang J, Kern TS. 2001. Abnormalities of Retinal Metabolism in Diabetes and Experiment Galactosemia. Diabetes; 50: 1938 42.

Lawrence J C, 1994. Insulin and Oral Hypoglcemic Agents, In Brody. T, M. Larner, J. Minneman, K,P, and Neu, H, C. (Ed.), Human Pharmacology. 2nd Ed., 523-539, Mosby, London.

Mayes PA. 2003. Struktur dan Fungsi

Vitamin Larut Lipid. Dalam Biokimia Harper, Edisi 25: Jakarta: EGC, Jakarta, 581-597.

Mohora Maria, Greabu Maria, Muscurel Corina, Duta Carmen, Totan Alexandra Totan. 2007. The Sources and the targets of oxidative stress in the etiology of diabetic complikastions. Romaniah J. Biophys , Vol 17, No 2, P 63-84. Bucharest
Murray P.A, Daryl K.G, Victor W.R. 2009. Biokimia Harper. Edisi 27. Jakarta: EGC

Nishikawa, T, et al. 2000. Normalizing mitochondrial superoxide production blocks three pathways of hyperglycaemic damage. Nature.404:787-790

Notoatmodjo, S., 2002. Metodologi Penelitian Kesehatan. Rineke Cipta. Jakarta

Proctor PH, Reyholds ES. 1984. Free Radical and Disease in Man Physiol Chem Phys Med. 16; 175 - 95.

Rand ML and Murray R K, 2001, Sel darah merah dan putih. Dalam: Murray RK, Granner DK, Mayes PA, Rodwell VW. Biokimia Harper. Edisi 25. Alih Bahasa: Hartono A. Jakarta: EGC. 2001: $727-42$.

Reusch Jane. 2003. Diabetes, microvascular complications, and cardiovascular complication; whats is it abaout glucose. The Journal of Clinical Investigation, Volume 112 number 7

Riset Kesehatan Dasar (RIKESDAS), 2007. Jakarta: Badan Penelitian dan Pengembangan Kesehatan, Departemen Kesehatan, Republik Indonesia

Rowland NE and Bellush LL, 1989. Diabetes mellitus: Stress Neurochemistry and Behavior, Neuroscience and Biobehavioral Review, 13 (4): 199 206.

Setyohadi B , 2006. Buku Ajar ILmu Penyakit Dalam Edisi IV. Jilid III. Jakarta: Pusat Penerbit Departemen. Ilmu Penyakit Dalam FKUI: 1857.

Schteigart D E, 1994. Metabolisme Glukosa dan Diabetes Mellitus. Dalam: Price SA, Wilson LM. Patofisiologi, Konsep Klinis. Proses-Proses Penyakit. Edisi 6. Volume 1. Alih Bahasa: Pendit BU, 
Hartono $\mathrm{H}$, Wulansari $\mathrm{P}$, Mahanani PA. Jakarta: EGC, 2005: 247-67.

Soriano G, F, Virag L, Jagtap P, Scabo E, Mabley J, Liaudet L, Marton A, et al . 2001. Diabetic Endothelial Dysfunction: The role of poly(ADPribose) polymerase: The role of poly(ADP-ribose) polymerase activation nature medicine

Suyono S, 2006. Buku Ajar Penyakit Dalam. Jilid III. Edisi 4. Jakarta: Departemen Ilmu Penyakit Dalam FKUI: 1857.

Sungkar MA. 2007. Hubungan antara pengendalian metabolik dan komplikasi kronik diabetes tipe 2 pada penyakit kardiovaskuler. Dalam Darmono, dll (eds), Naskah Lengkap Diabetes Melitus ditinjau dari berbagai aspek penyakit dalam. Badan penerbit universitas Diponegoro. Semarang. 257-65.

Unger RH, Foster DW, 1992. Diabetes Mellitus. In Wilson, J.D and Foster, D.W, Endocrinology, 1255 - 1317, W,B Sunders Company. A Division of Harcourt Brace and Company. London

Virag Laszlo, Scabo czabo. 2002. The therapeutic Potential of Poly(ADPribose) Polymerase Inhibition. Pharmacol Rev: 54: 375 - 429

Wild, S., Sicree, R. 2004. Global Prevalence of DM. 2004: Diabetes Care 27,1047 53

Yerizel E. 2011. Kerusakan DNA Akibat Hiperglikemia dan Pengaruhnya terhadap Aktivitas Poly (ADP) Ribosa Polymerase (Parp) Pada Penderita Diabetes Melitus. Universitas Andalas. 